\title{
Activation and pathway of glucosylglycerol synthesis in the cyanobacterium Synechocystis sp. PCC 6803
}

\author{
Martin Hagemann and Norbert Erdmann
}

Author for correspondence: Martin Hagemann. Tel: +49381395 353. Fax: +49381395352.

Department of Biology, University of Rostock, 18051 Rostock, FRG

\begin{abstract}
The biosynthetic pathway of glucosylglycerol (GG), the osmoprotective compound of Synechocystis sp. PCC 6803, was found to proceed from ADPglucose and glycerol 3-phosphate via glucosylglycerol phosphate in a two-step reaction. Using an in vitro assay it was shown that the GG-forming enzyme system required activation, which could be initiated in vivo by hypertonic salt concentrations and osmotic shock, or in vitro by $\mathrm{NaCl}$ addition at the stage of enzyme extraction or assay.
\end{abstract}

Keywords: Synechocystis, glucosylglycerol synthesis, osmoprotection, salt activation

\section{INTRODUCTION}

Synthesis of an osmoprotective compound represents a fundamental part of the strategy of salt adaptation in plants, algae and micro-organisms. One of about 30 such compounds known today is the heteroside $O-\alpha-\mathrm{D}-$ glucopyranosyl- $(1 \rightarrow 2)$-glycerol (glucosylglycerol; GG) (Reed \& Stewart, 1988; Trüper \& Galinski, 1989). GG accumulates mostly in cyanobacteria in response to external salt concentration (Borowitzka et al., 1980; Erdmann, 1983) and enables the organisms to survive moderate salinities (Mackay et al., 1983; Reed et al., 1984).

GG is absent in unstressed cells and is synthesized immediately after a salt shock (Erdmann $e t$ al., 1992) to an intracellular concentration which corresponds to the strength of the stress, and without marked turnover (Hagemann et al., 1987). After a downshock, the necessary rapid depletion of the accumulated GG is achieved by turnover (Warr et al., 1985; Tel-Or et al., 1986) or excretion (Fulda et al., 1990). Although glycogen has been shown to be a possible precursor of GG (Tel-Or et al., 1986), it seems likely that this pathway is of limited value only and may be restricted to the early period of the adaptation course or to darkness (Erdmann et al., 1989). The majority of GG is synthesized by light-dependent $\mathrm{CO}_{2}$ photoassimilation (Mackay \& Norton, 1987).

Little is known about the biochemical pathway leading to GG (Reed \& Stewart, 1988). All osmoprotective compounds structurally related to GG (isofloridoside, floridoside, sucrose and trehalose) are synthesized via a unique

Abbreviations: ADP-GIC, adenosine diphosphate glucose; GG, glucosylglycerol; GGP, glucosylglycerol phosphate; G3P, glycerol 3-phosphate; UDP-GIC, uridine diphosphate glucose. pathway (Brunner \& Kauss, 1988; Giæver et al., 1988). In each case the respective UDP sugar is combined with the appropriate polyol phosphate, yielding a phosphorylated intermediate which is hydrolysed to the free osmoprotective compound. Reed \& Stewart (1988) have proposed that GG is formed in a similar manner from UDP-Glc and glycerol 3-phosphate (G3P) via the intermediary glycosylglycerol phosphate (GGP).

The present work was done to determine the pathway of GG synthesis in the cyanobacterium Synechocystis sp. PCC 6803.

\section{METHODS}

Culture conditions. Axenic cells of the unicellular cyanobacterium Synechocystis sp. PCC 6803 were grown in the medium of Allen \& Arnon (1955), containing $2 \mathrm{mM} \mathrm{NaCl}$, in continuous light $\left(20 \mathrm{~W} \mathrm{~m}^{-2}\right)$ at $30^{\circ} \mathrm{C}$ and aerated by $\mathrm{CO}_{2}$-enriched air $(5 \%$, $\mathrm{v} / \mathrm{v})$. Salt-adapted cells were obtained by cultivation of Synechocystis for $5 \mathrm{~d}$ in Allen \& Arnon's medium containing $324 \mathrm{mM} \mathrm{NaCl}$. Salt or osmotic stress experiments were performed by adding the desired osmolyte in solid form to the medium. After the times indicated, cells were harvested and used for the estimation of enzyme activities. Bacterial contamination was checked by spreading $0.2 \mathrm{ml}$ of the cyanobacterial suspension on LB agar plates and incubating at $30^{\circ} \mathrm{C}$ for $36 \mathrm{~h}$.

Preparation of crude enzyme extract. Aliquots of the cyanobacterial suspension (10 ml; $\mathrm{OD}_{750}$ approx. 1.5) were centrifuged at $4000 \mathrm{~g}$ for $3 \mathrm{~min}$. The pellet was resuspended in $400 \mu \mathrm{l}$ ice-cold homogenization buffer containing the same amount of $\mathrm{NaCl}$ or organic osmolyte used in the shock experiments (50 mM HEPES, pH 7.8, $10 \mathrm{mM} \mathrm{MgCl}_{2}, 2 \mathrm{mM}$ EDTA, $0 \cdot 1 \%$ human serum albumin and, as required, $324 \mathrm{mM} \mathrm{NaCl}$, $684 \mathrm{mM} \mathrm{NaCl}$ or $1.3 \mathrm{M}$ sucrose). Cells were broken by sonication $(2 \mathrm{~min}$ at $30 \mathrm{~W})$ under permanent ice cooling. After 


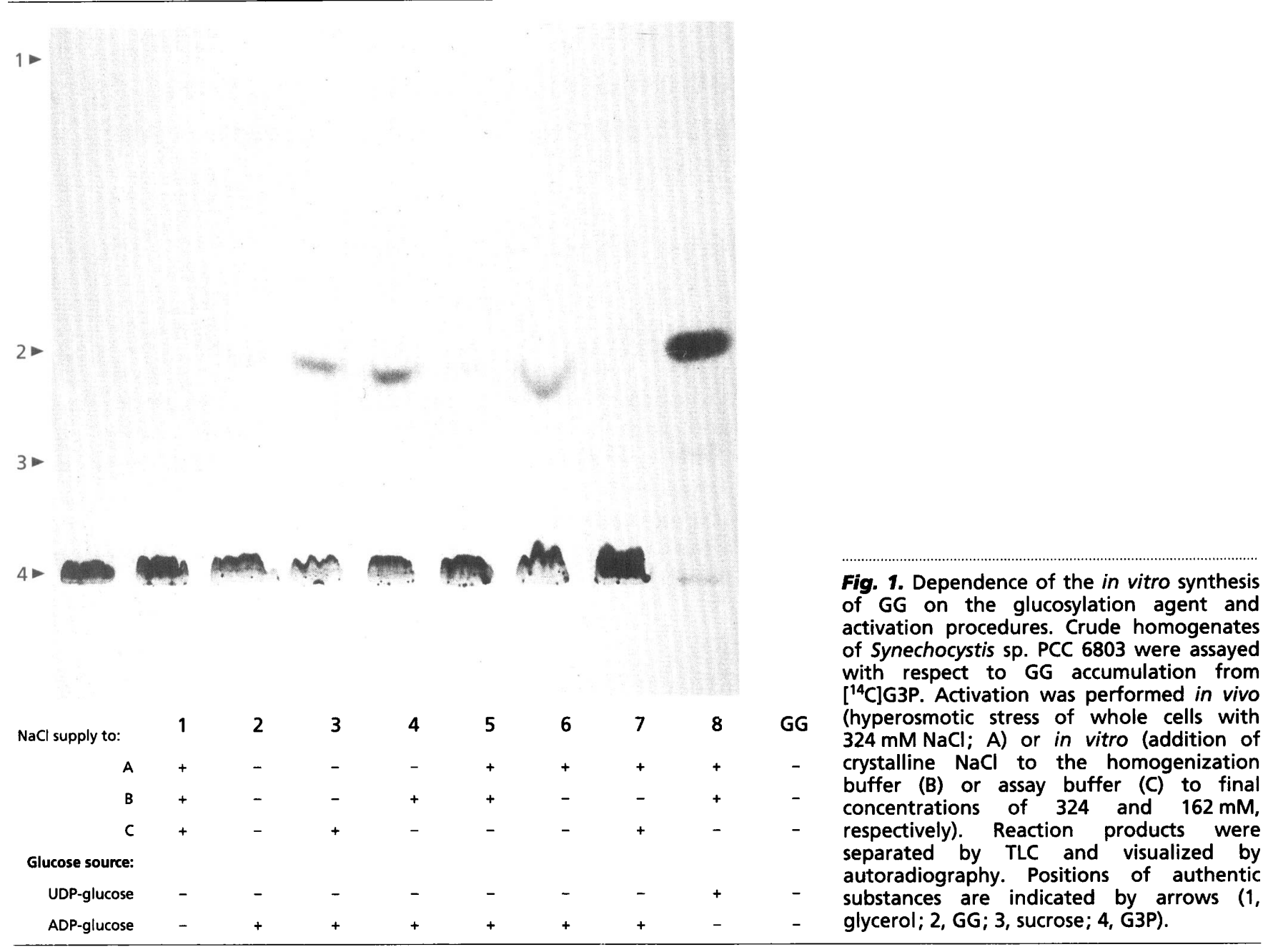

centrifugation $\left(5000 \mathrm{~g}\right.$ at $4{ }^{\circ} \mathrm{C}$ for $\left.10 \mathrm{~min}\right)$ the supernatant was used directly as a crude enzyme extract. The enzyme assays were started approximately $20 \mathrm{~min}$ after harvesting the cells. There were no differences in enzyme activities if the cells or the enzyme extracts were frozen and stored at $-20^{\circ} \mathrm{C}$ prior to the enzyme assays.

GGP synthase/phosphatase assay. The assay mixture contained $5 \mu \mathrm{l}$ assay buffer (250 mM HEPES, pH 7.8, $50 \mathrm{mM}$ $\mathrm{MgCl}_{2}, 10 \mathrm{mM}$ EDTA and $0.5 \%$ human serum albumin), $5 \mu \mathrm{ADP}-\mathrm{Alc}(6 \mathrm{mM}), 5 \mu \mathrm{l} \mathrm{L}-\left[\mathrm{U}-{ }^{14} \mathrm{C}\right] \mathrm{G} 3 \mathrm{P}(18.5 \mathrm{kBq}$, specific activity $3.7 \mathrm{GBq} \mathrm{mmol}^{-1}$, Amersham, containing $3 \mathrm{mM} \mathrm{G} 3 \mathrm{P}$ [dicyclohexylammonium salt]), $5 \mu$ l benzamidine chloride $(50 \mathrm{mM})$ and, as required, $5 \mu \mathrm{l} \mathrm{NaCl}(1.7 \mathrm{M})$. The volume was brought to $50 \mu \mathrm{l}$ with water. The reaction was started by the addition of the crude enzyme extract $(20 \mu \mathrm{l})$ and terminated after $10 \mathrm{~min}$ at $30^{\circ} \mathrm{C}$ by the addition of $400 \mu \mathrm{l}$ acetone. Protein was precipitated at $-20^{\circ} \mathrm{C}$ for at least $3 \mathrm{~h}$. The sample was centrifuged $\left(14000 \mathrm{~g}, 4^{\circ} \mathrm{C}, 15 \mathrm{~min}\right)$ and the supernatant lyophilized. The residue was treated with $25 \mu \mathrm{l}$ ethanol $(80 \%, \mathrm{v} / \mathrm{v})$ and an aliquot $(5 \mu \mathrm{l})$ of the alcoholic solution spotted onto a thinlayer plate (usually HPTLC KG 60; Merck). TLC was performed in acetonitrile/water $(85: 15, \mathrm{v} / \mathrm{v})$ and repeated three times with careful drying after each run.

For the determination of the whole spectrum of reaction products, aliquots of the enzyme assays were additionally separated by two-dimensional TLC (see Erdmann, 1983). Authentic ${ }^{14} \mathrm{C}$-labelled GG was obtained from ${ }^{14} \mathrm{C}$-labelled saltadapted cells of Microcystis firma after purification by ion- exchange chromatography (Hagemann et al., 1987). Labelled compounds were detected by autoradiography.

GG. The amount of $\left[{ }^{14} \mathrm{C}\right] \mathrm{GG}$ synthesized in vitro was estimated by densitometry or liquid scintillation counting. In the former case autoradiogram spots were quantified by means of a video densitometer (Bio-Profil; Vilber Lourmat) using brightness and area of the spots. For liquid scintillation counting the spots were marked on the chromatogram according to their position on the autoradiogram, scraped off and placed into a scintillation vial with $5 \mathrm{ml}$ cocktail [toluene/Triton X-100 (2:1, v/v), PPO $(0 \cdot 4 \%)$, dimethyl-POPOP, $(0 \cdot 012 \%)$ ]. Results were expressed as radioactivity incorporated into GG ( $\mu \mathrm{g}$ protein $)^{-1}$. Protein was estimated according to Bradford (1976). All experiments were performed at least three times.

\section{RESULTS}

\section{In vitro assay for GGP synthase/phosphatase}

The biosynthesis of GG requires the glucosylation of glycerol. UDP-Glc and ADP-Glc were compared as possible substrates for glucosylation of G3P. GG was only synthesized in those tests which contained ADP-Glc (Fig. 1, lanes 3-7); substitution of ADP-Glc by UDP-Glc under otherwise optimal conditions prevented GGsynthesis (compare lanes 8 and 5 in Fig. 1).

On the basis of this result, a radiochemical assay for the 


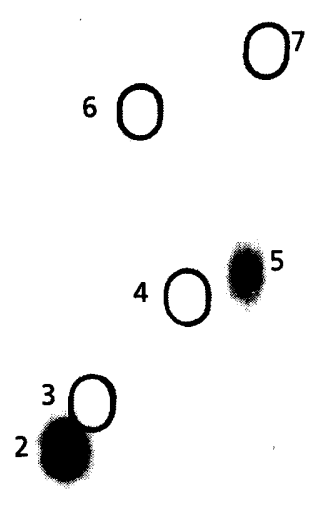

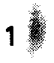

Fig. 2. Identification of the reaction products from the in vitro synthesis of GG. The assay was performed as in Fig. 1. Separation of the reaction products was done by twodimensional TLC. Black spots, labelled reaction products; open circles, non-labelled marker amino acids. 1, GGP; 2, G3P; 3, aspartic acid; 4, glutamic acid; 5, GG; 6, citrulline; 7, alanine. The origin is not shown.

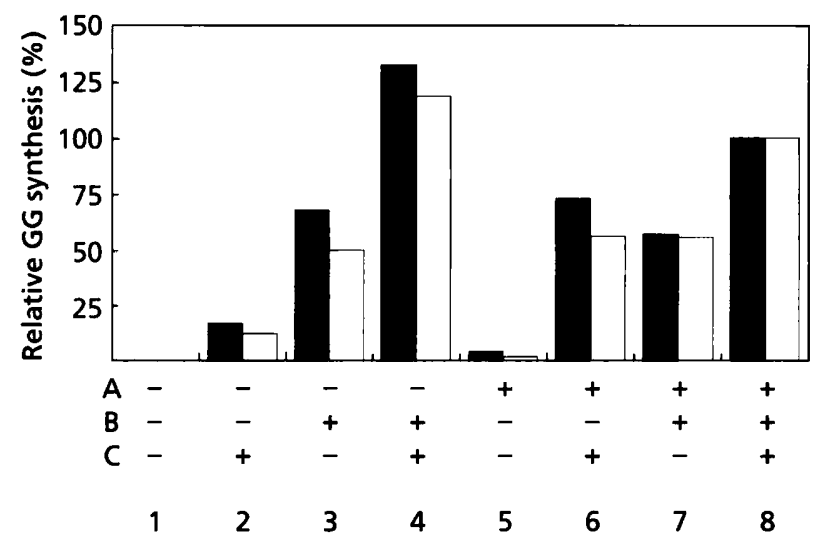

Fig. 3. Activation of the GG-forming enzyme system by $\mathrm{NaCl}$ in vivo and in vitro. $\mathrm{NaCl}$ was added to the culture medium (A; $324 \mathrm{mM})$, homogenization buffer $(B ; 324 \mathrm{mM})$ and assay (C; $170 \mathrm{mM}$ ) buffer, respectively, to yield the concentrations indicated. The assay was performed as in Fig. 1. GG was estimated by densitometry $(\square)$ and by liquid scintillation counting ( $\square$ ); the mean value of experiment 8 was set to $100 \%$.

GG-forming enzyme system was developed, using ADPGlc and $\left[{ }^{14} \mathrm{C}\right] \mathrm{G} 3 \mathrm{P}$ as substrates. GGP should be the intermediary product of $G G$ biosynthesis. When assay samples were analysed by two-dimensional TLC, only three spots were detected (Fig. 2). Two of these were identified as GG and G3P by rechromatography and

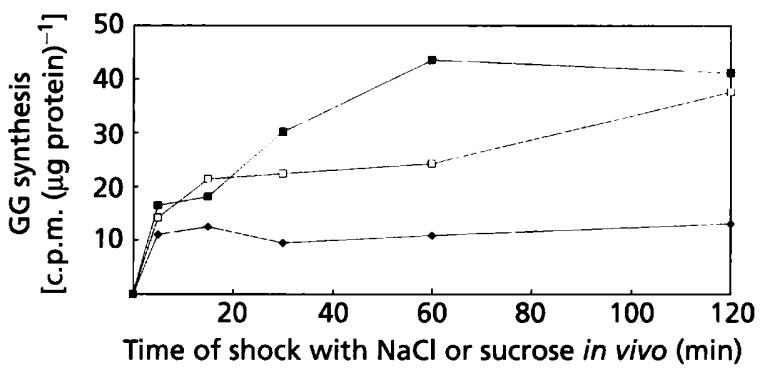

Fig. 4. Activity of the GG-forming enzymes after application of salt or organic osmolytes. The osmolytes were added to the culture medium [final concentration $324 \mathrm{mM} \mathrm{NaCl}$ (口), $648 \mathrm{mM} \mathrm{NaCl}(\square)$ and $1.3 \mathrm{M}$ sucrose ( $\diamond)$, respectively]; cells were harvested and homogenized after the times indicated. Homogenization, but not the assay, was performed in the presence of the osmolytes. GG was estimated by liquid scintillation counting. The values shown are means of four experiments.

comparison with authentic substances. The third spot yielded only GG following treatment with alkaline phosphatase and rechromatography (data not shown), suggesting its likely identity to be GGP. Usually, GGP formation was weak or undetectable.

\section{In vivo and in vitro activation of the GG-synthesizing enzyme system}

Enzyme extracts made from unstressed cells of Synechocystis sp. PCC 6803 were unable to synthesize GG (Fig. 1, lane 2). An extract of salt-stressed cells showed only poor activity (Fig. 1, lane 6). Activity could be markedly increased when $\mathrm{NaCl}$ was added to the homogenization or assay buffer using both unstressed (Fig. 1, lanes 3 and 4) and salt-stressed (Fig. 1, lanes 5 and 7) cells.

Activation of the GG-synthesizing enzyme achieved by in vivo salt shock ( $30 \mathrm{~min}, 324 \mathrm{mM} \mathrm{NaCl}$ ) was substantially lost in vitro during $\mathrm{NaCl}$-free manipulations (Fig. 3, column 5). However, activation could be retained when $\mathrm{NaCl}$ was present at the homogenization stage (Fig. 3, column 7), or restored when $\mathrm{NaCl}$ was included in the assays (Fig. 3, column 6), and was at a maximum when $\mathrm{NaCl}$ was present throughout the procedure (Fig. 3, column 8). GG synthesis could also be activated in unstressed cells in vitro by $\mathrm{NaCl}$ addition at the stage of homogenization, assay, or both (Fig. 3, columns 3, 2 and 4 , respectively).

Enzyme activation achieved at one stage was not completely lost during subsequent $\mathrm{NaCl}$-free stages. This can be seen from tests in which $\mathrm{NaCl}$ was omitted from the assay (Fig. 3, columns 3 and 7) or homogenization (Fig. 3, columns 2 and 6) stages. When $\mathrm{NaCl}$ was omitted from both homogenization and assay stages, a low, but detectable, enzyme activity was found (Fig. 3, column 5).

A detailed survey of the in vivo activation was obtained by time-response studies using different shock-times, strengths and osmolytes (Fig. 4). A rapid activation of the GG-synthesizing enzymes was observed immediately 
after applying the osmolytes ( $324 \mathrm{mM} \mathrm{NaCl}, 684 \mathrm{mM}$ $\mathrm{NaCl}$ and $1.3 \mathrm{M}$ sucrose, respectively). In all cases the enzyme activities achieved the same order of magnitude during the first minutes after each shock treatment. The rapid activity increase was followed by a moderate increase up to $1-2 \mathrm{~h}$ which was more distinct for the lower $\mathrm{NaCl}$ concentration and was absent in the case of sucrose (Fig. 4).

\section{Properties of the GG-forming enzyme system}

Among three salts tested, $\mathrm{NaCl}$ had the most pronounced activating effect; $\mathrm{KCl}$ was less effective (approximately $50 \%$ of the activity of $\mathrm{NaCl}$ ) and $\mathrm{NaNO}_{3}$ induced a small activation only (less than $10 \%$ of the activation obtained by $\mathrm{NaCl}$ ). Iso-osmolar concentrations of organic osmolytes were unable to induce GG synthesis in vitro (not shown); sucrose was effective in vivo (Fig. 4), but not in vitro (not shown). The enzyme system was cold resistant and could be extracted from lyophilized cells. Among three $\mathrm{pH}$ values tested, activity was highest at $\mathrm{pH} 8.5$ and was reduced at lower $\mathrm{pH}$ values $(78 \%$ at $\mathrm{pH} 7 \cdot 8 ; 50 \%$ at

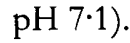

To study the localization of the enzyme system in the cell, the homogenate was centrifuged at high speed $(46000 \mathrm{~g})$. Apart from some loss of activity, caused perhaps during centrifugation, the activity of the soluble fraction was similar to that of the crude homogenate, while it was much smaller or absent in the membrane fraction (not shown).

\section{DISCUSSION}

In the present work, it has been shown that the precursor of GG synthesis in Synechocystis sp. PCC 6803 is ADP-Glc and not UDP-Glc. This contrasts with, for example, isofloridoside synthesis in Poterioochromonas malhamensis (Kauss, 1987) and trehalose synthesis in Escherichia coli (Giæver et al., 1988) and Ectotbiorbodospira balocbloris (Lippert et al., 1993), which are strictly dependent on UDP-sugars (UDP-galactose and UDP-Glc, respectively), no trehalose being formed using ADP-Glc. However, in a few cases, ADP-Glc-dependent trehalose synthesis has been reported (Lippert et al., 1993).

As expected, the reaction products were GG and GGP, although the latter did not accumulate in appreciable amounts. Obviously, GGP was rapidly dephosphorylated to GG, the massive accumulation of which was essential for adaptation to enhanced salt concentrations. Thus, the reaction proceeded in the following manner:

$$
\mathrm{ADP}-\mathrm{Glc}+\mathrm{G} 3 \stackrel{1}{\rightarrow} \mathrm{ADP}+(\mathrm{GGP}) \stackrel{2}{\rightarrow} \mathrm{ADP}+\mathrm{GG}+\mathrm{P}_{\mathrm{i}}
$$

Enzymes: 1, ADP-glucose: glycerol-3-phosphate 2glycosyltransferase (GGP synthase; EC 2.4.1.-); 2, glucosylglycerol-3-phosphate phosphohydrolase (GGP phosphatase; EC 3.1.3.-).

The in vitro assay developed here involved both enzyme activities, but reflected almost completely the synthase reaction. The phosphatase reaction was not rate limiting since addition of alkaline phosphatase did not significantly enhance the yield of GG (data not shown). The occurrence of the phosphatase reaction could be shown indirectly by addition of the phosphatase inhibitor $\mathrm{NaF}$, which suppressed GG formation (data not shown). For trehalose synthesis in bakers' yeast, it has been shown that the same protein has both enzyme activities (Londesborough \& Vuorio, 1991).

The GG-forming enzyme system seems to involve a soluble protein which is present in a preformed, inactive state in unstressed cells and requires activation. This was achieved mainly in vivo by stressing intact cells of Synechocystis sp. PCC 6803 with $\mathrm{NaCl}$-containing media, but also in vitro by adding $\mathrm{NaCl}$ to the homogenization buffer or assay buffer. $\mathrm{KCl}$ and, especially, $\mathrm{NaNO}_{3}$ were less effective; organic osmolytes failed to stimulate the enzyme system at all (glucose, glycerol; data not shown), or showed only a stimulatory effect in vivo (sucrose). The activation was reversible, since activation attained at one stage was progressively lost if the next step was without $\mathrm{NaCl}$, but could be restored by the addition of $\mathrm{NaCl}$. The low enzyme activity found in extracts from salt-stressed cells under $\mathrm{NaCl}$-free homogenization and assay conditions (see Fig. 3, column 5) might be due to $\mathrm{NaCl}$ remaining as a result of insufficient dilution during extract preparation (3.5-fold dilution at the step from homogenization to assay, and about 3-fold dilution at the suspension of the cell pellet prior to homogenization).

The salt-dependent activation may involve two mechanisms. This can be concluded from the two-phase activation kinetics found after a salt shock on cells of Synechocystis sp. PCC 6803 (in vivo activation; see Fig. 4). The rapid activation immediately after the salt shock may represent post-translational modification. This mechanism could also be responsible for the rapid activation of GGsynthesis in vitro. A similar post-translational activation mechanism has been reported for trehalose synthesis in $E$. coli after an osmotic shock. Trehalose-6-phosphate synthase is activated by high amounts of $\mathrm{KCl}$ and other ions by direct stimulation of the enzyme, and also by the induction of transcription (Giæver et al., 1988; Boos et al., 1990). Altered gene expression can also be postulated for GG synthesis in Synechocystis sp. PCC 6803, since the in vivo activation process involves a long-term component (2.5fold increase of enzyme activity within $2 \mathrm{~h}$; see Fig. 4), which might be due to de novo protein synthesis. However, this seems to be of less importance, since earlier results have indicated that de novo protein synthesis is not necessary for the activation of GG synthesis (Hagemann et al., 1990; Erdmann et al., 1992).

The mechanism of post-translational modification is unknown. The related isofloridoside-phosphate synthase, which shows a similar activation/deactivation behaviour to the GG-forming enzyme system, is activated posttranslationally by limited proteolysis with a membraneassociated protease which can be activated in vivo $(\mathrm{NaCl})$ and in vitro $\left(\mathrm{Ca}^{2+}\right.$ or detergents; Brunner \& Kauss, 1988).

Other glucosyl transferases, such as $\beta$-glucan synthase and sucrose-phosphate synthase, are known to be regulated by 
their phosphorylation/dephosphorylation status (Paliyath \& Poovaiah, 1988; Huber \& Huber, 1992). Covalent modification by protein phosphorylation is now thought to be a major mechanism for the control of cytoplasmic enzyme activities. It is therefore possible that the GGsynthesizing enzyme system is regulated in the same manner. This is supported by the identification of protein phosphorylation/dephosphorylation during salt adaptation of Synechocystis sp. PCC 6803 and î́s dependence on $\mathrm{NaCl}$ treatment in the same manner as $\mathrm{GG}$ synthesis (Hagemann et al., 1993).

\section{ACKNOWLEDGEMENTS}

This work was supported by a grant from the Deutsche Forschungsgemeinschaft, FRG. We thank Mrs Ilse Dörr and Chem.-Ing. Karin Sommerey for their excellent technical assistance.

\section{REFERENCES}

Allen, M. B. \& Arnon, D. I. (1955). Studies on nitrogen-fixing bluegreen algae. I. Growth and nitrogen fixation by Anabaena cylindrica Lemm. Plant Physiol 30, 366-372.

Boos, W., Ehmann, U., Forkl, H., Klein, W., Rimmele, M. \& Postma, P. (1990). Trehalose transport and metabolism in Escherichia coli. $J$ Bacteriol 172, 3450-3461.

Borowitzka, J. L., Demmerle, S., Mackay, M. A. \& Norton, R. (1980). Carbon-13 nuclear magnetic resonance study of osmoregulation in a blue-green alga. Science 210, 650-651.

Bradford, M. M. (1976). A rapid and sensitive method for the quantitation of microgram quantities of protein using the principle of protein-dye binding. Anal Biochem 72, 248-254.

Brunner, G. \& Kauss, H. (1988). Deaggregation and proteolytic modification of a galactosyltransferase of Poterioochromonas malbamensis. Pbysiol Plant 74, 708-714.

Erdmann, N. (1983). Organic osmoregulatory solutes in blue-green algae. Z Pfanzenphysiol 110, 147-155.

Erdmann, N., Berg, C. \& Hagemann, M. (1989). Missing salt adaptation of Microcystis firma (cyanobacterium) in the dark. Arch Hydrobiol 114, 521-530.

Erdmann, N., Fulda, S. \& Hagemann, M. (1992). Glucosylglycerol accumulation during salt acclimation of two unicellular cyanobacteria. J Gen Microbiol 138, 363-368.

Fulda, S., Hagemann, M. \& Libbert, E. (1990). Release of glucosylglycerol from the cyanobacterium Synechocystis spec. SAG 92.79 by hypoosmotic shock. Arch Microbiol 153, 405-408.

Giæver, H. M., Styrvold, O. B., Kaasen, I. \& Strom, A. R. (1988). Biochemical and genetic characterization of osmoregulatory trehalose synthesis in Escherichia coli. J Bacteriol 170, 2841-2849.
Hagemann, M., Erdmann, N. \& Wittenburg, E. (1987). Synthesis of glucosylglycerol in salt-stressed cells of the cyanobacterium Microcystis firma. Arch Microbiol 148, 275-279.

Hagemann, M., Wölfel, L. \& Krüger, B. (1990). Alterations of protein synthesis in the cyanobacterium Synechocystis sp. PCC 6803 after a salt shock. J Gen Microbiol 136, 1393-1399.

Hagemann, M., Golldack, D., Biggins, J. \& Erdmann, N. (1993). Salt-dependent protein phosphorylation in the cyanobacterium Synecbocystis sp. PCC 6803. FEMS Microbiol Lett 113, 205-210.

Huber, S. C. \& Huber, J. L. (1992). Role of sucrose-phosphate synthase in sucrose metabolism in leaves. Plant Pbysiol 99, 1275-1278.

Kauss, H. (1987). Some experiments of calcium-dependent regulation in plant metabolism. Annu Rev Plant Physiol 38, 47-72.

Lippert, K., Galinski, E. A. \& Trüper, H. G. (1993). Biosynthesis and function of trehalose in Ectothiorbodospira halocbloris. Antonie Leeuwenboek 63, 85-91.

Londesborough, J. \& Vuorio, O. (1991). Trehalose-6-phosphate synthase/phosphatase complex from bakers' yeast: purification of a proteolytically activated form. J Gen Microbiol 137, 323-330.

Mackay, M. A. \& Norton, R. S. (1987). ${ }^{13} \mathrm{C}$ nuclear magnetic resonance study of biosynthesis of glucosylglycerol by a cyanobacterium under osmotic stress. J Gen Microbiol 133, 1535-1542.

Mackay, M. A., Norton, R. S. \& Borowitzka, L. J. (1983). Marine blue-green algae have a unique osmoregulatory system. Mar Biol 73, 301-307.

Paliyath, G. \& Poovaiah, B.W. (1988). Promotion of $\beta$-glucan synthase activity in corn microsomal membranes by calcium and protein phosphorylation. Plant Cell Physiol 29, 67-73.

Reed, R. H. \& Stewart, W. D. P. (1988). The response of cyanobacteria to salt stress. In Biochemistry of the Algae and Cyanobacteria, vol. 12, pp. 217-231. Edited by L. J. Rogers \& J. R. Gallon. Oxford: Clarendon Press.

Reed, R. H., Richardson, D. L., Warr, S. R. C. \& Stewart, W. D. P. (1984). Carbohydrate accumulation and osmotic stress in cyanobacteria. J Gen Microbiol 130, 1-4.

Tel-Or, E., Spath, S., Packer, L. \& Mehlhorn, R. J. (1986). Carbon13 NMR studies of salt shock-induced carbohydrate turnover in the marine cyanobacterium Agmenellum quadruplicatum. Plant Physiol 82, 646-652.

Trüper, H. G. \& Galinski, E. A. (1989). Compatible solutes in halophilic phototrophic procaryotes. In Microbial Mats: Physiological Ecology of Bentbic Microbial Communities, pp. 342-348. Edited by Y. Cohan \& E. Rosenberg. Washington DC: American Society for Microbiology.

Warr, S. R. C., Reed, R. H., Chudek, J. A., Foster, R. \& Stewart, W. D. P. (1985). Osmotic adjustment in Spirulina plantensis. Planta 163, 424-426.

Received 2 August 1993; revised 2 November 1993; accepted 15 December 1993. 